\title{
The clinical outcomes of the newborns of the preeclamptic mothers
}

\author{
Öznur Tiryaki' (D), Özge Karakaya Suzan² (D), Sevin Altınkaynak² (D), ibrahim Caner ${ }^{3}$ \\ ${ }^{1}$ Training and Research Hospital of Sakarya University, Sakarya, Turkey \\ ${ }^{2}$ Department of Pediatric Nursing, Nursing Department, Faculty of Health Sciences, Sakarya University, Sakarya, Turkey \\ ${ }^{3}$ Division of Neonatology, Department of Pediatrics, Sakarya Training and Research Hospital, Faculty of Medicine, Sakarya University, Turkey
}

\begin{abstract}
Objective: We planned this study to investigate the characteristics of the newborns retrospectively in company with the literature, who were hospitalized in the neonatal intensive care unit, of the mothers diagnosed with maternal preeclampsia/eclampsia.

Methods: The discharge reports received from the hospital information management system for the newborns monitored, examined and treated in the neonatal intensive care unit in the postnatal period after they were delivered with the diagnosis of preeclampsia/eclampsia between January 1 and December 31, 2018 in a training and research hospital were assessed retrospectively after obtaining the approvals of hospital management and ethics committee.

Results: Mean age of the mothers of 51 newborns included in the study was $32.21 \pm 6.20$, the week of gestation during delivery was $34.21 \pm$ 3.33 , and the mean birth weight of the newborns was $2177 \pm 1007 \mathrm{~g}$. It was found that almost all women (98\%) conceived spontaneously, $9.8 \%(n=5)$ of them were twin pregnancies, and $31.4 \%(n=16)$ of them had additional diseases (gestational diabetes, epilepsy, and hypothyroid). During the hospitalization in the clinic, $58.8 \%$ of the newborns received nasal continuous positive airway pressure (N-CPAP) support, $5.9 \%$ of them received mechanical ventilator support, and $51 \%$ of them received intermittent phototherapy. The days switching to full enteral of the newborns were $10.72 \pm 13.87$ (range: $1-64$ ). Three newborns died on 2nd, 12th, and 23rd days of their hospitalization. Of the newborns, $90.2 \%$ were fed by only breastfeeding while $9.8 \%$ were fed by both breastfeeding and formula before they were discharged.

Conclusion: In the approach towards the newborns of preeclamptic women, we believe that perinatal mortality and morbidity associated with preeclampsia will be decreased by noticing all issues early that may develop, such as prematurity and the complications developing secondary to prematurity in particular, improving the conditions of neonatal intensive care unit, and establishing multidisciplinary teams.
\end{abstract}

Keywords: Preeclampsia, neonatal intensive care unit, mortality, morbidity.

\section{Özet: Preeklamptik anne bebeklerinin klinik sonuçları}

Amaç: Bu çalısma yenidoğan yoğun bakım ünitesinde yatan, maternal preeklampsi/eklampsi tanısı olan annelerin bebeklerinin özelliklerinin retrospektif olarak literatür eşliğinde incelenmesi amaciyla planlandı.

Yöntem: Bir eğitim ve araştırma hastanesinde 1 Ocak - 31 Aralık 2018 tarihleri arasında preeklampsi/eklampsi tanısıyla doğumu gerçekleşen, doğum sonrası aynı hastanenin yenidoğan yoğun bakım ünitesinde yatırılarak izlem, tetkik ve tedavisi yapılan bebeklerin hastane bilgi yönetim sisteminden elde edilen epikriz dosyaları, hastane yönetimi ve etik kurul onayı alındıktan sonra incelenerek retrospektif olarak değerlendirildi.

Bulgular: Çalışmaya dahil edilen 51 bebeğin annelerinin yaş ortalaması $32.21 \pm 6.20$, bebeklerin doğduklarındaki gebelik haftası $34.21 \pm$ 3.33 , ortalama doğum ağırlıkları $2177 \pm 1007$ gram olarak bulundu. Annelerin neredeyse tamamının (\%98) spontan (kendiliğinden) gebe kaldığı, \%9.8'inin ( $\mathrm{n}=5)$ ikiz gebelik olduğu, \%31.4'ünün $(\mathrm{n}=16)$ ek hastalıklarının (gestasyonel diyabet, epilepsi, hipotiroidi) olduğu saptandı. Kliniğe kabul edilen bebeklerin yatışlı oldukları günlerde \% 58.8'i nazal sürekli pozitif hava yolu basınç desteği, \% 5.9'u mekanik ventilatör desteği, \% 51 'i aralıklı fototerapi aldı. Bebeklerin tam enterale geçiş günleri $10.72 \pm 13.87$ (aralık: 1-64) olarak belirlendi. Bebeklerinden 3 tanesi yatışlarının 2. günü, 12. günü ve 23. gününde hayatını kaybetmişti. Bebeklerin \%90.2'si sadece anne sütü (anne memesini emerek), \%9.8'i hem anne sütü hem de mama alarak taburcu olmuştu.

Sonuç: Preeklamptik anne bebeklerine yaklaşımda; prematürite ve buna sekonder gelişen komplikasyonlar başta olmak üzere gelişebilecek diğer sorunların erken dönemde fark edilmesi, yenidoğan yoğun bakım ünitesi koşullarının düzenlenmesi ve multidisipliner ekiplerin oluşturulması ile preeklampsiye bağlı gelişen perinatal mortalite ve morbiditenin azaltılacağı kanısındayız.

Anahtar sözcükler: Preeklampsi, yenidoğan yoğun bakım ünitesi, mortalite, morbidite.

Correspondence: Öznur Tiryaki, PhD. Training and Research Hospital of Sakarya University, Sakarya, Turkey.

e-mail: oznuritiryaki@gmail.com / Received: November 24, 2019; Accepted: December 21, 2019

Please cite this article as: Tiryaki Ö, Karakaya Suzan Ö, Altınkaynak S, Caner İ. The clinical outcomes of the newborns of the preeclamptic mothers. Perinatal Journal 2019;27(3):155-160. doi:10.2399/prn.19.0273006 


\section{Introduction}

Preeclamptic/eclamptic pregnancy is among the significant morbidity and mortality reasons for mother and fetus. Its prevalence varies between $5 \%$ and $7 \% .{ }^{[1,2]}$ The negative maternal outcomes of preeclampsia/eclampsia (PE/E) are severe hypertension, ablatio placentae, cerebral hemorrhage, pulmonary edema, liver and kidney failure, stroke, hemorrhage, intrauterine fetal death, HELLP (hemolysis, elevated liver enzymes, low platelet) syndrome, and maternal death. ${ }^{[1,3-5]}$ In pregnant women younger than 35 years old, maternal death associated with hypertension in $\mathrm{PE} / \mathrm{E}$ is the second among all maternal death causes. In this pregnancy group, rapid diagnosis, efficient treatment and mature delivery may prevent maternal deaths. ${ }^{[6]}$

The conditions such as history of $\mathrm{PE} / \mathrm{E}$ in previous pregnancies or in the family, nulliparity, black race, heritage, multiple pregnancy, obesity, polyhydramnios, oligohydramnios, molar pregnancy, diabetes mellitus, chronic hypertension, renal disease, age being $<20-40>$, low level of socio-economical status, non-immune fetal hydrops, connective tissue diseases, lack of nutrition and malnutrition increase the incidence of $\mathrm{PE} .^{[7]}$

The major disorder affecting fetus in PE negatively is the uteroplacental ischemia. ${ }^{[8]}$ Decreased uteroplacental blood flow leads to intrauterine hypoxia and may cause functional and structural disorders in many organs of fetus. The hypoxic stimulation increases the production of free oxygen radicals which have a significantly damaging impact. The brain of newborn which grows rapidly is affected negatively. ${ }^{[9]}$ In case of a severe placental insufficiency, the lack or reversal of umbilical arterial enddiastolic flow, the redistribution of mid-cerebral artery flow and an increase in the umbilical vein pulse occur in fetus. The intrauterine growth retardation (IUGR), preterm labor and fetal death are seen most frequently as the results of intrauterine hypoxemia. ${ }^{[8]}$ In the newborns where maternal PE/E and prematurity are seen at the same time, the complications such as respiratory distress syndrome (RDS), necrotizing enterocolitis (NEC), intraventricular hemorrhage (IVH), bronchopulmonary dysplasia (BPD), and perinatal death may develop. ${ }^{[7]}$ In a study comparing the newborns of women with PE and normal newborns, it was seen that the rate of IUGR was six times higher in the newborns of pregnant women diagnosed with PE than the normal newborns. ${ }^{[10]}$ It is known that about half of the newborns of the pregnant women with $\mathrm{PE}$ require neonatal intensive care unit (NICU) after delivery. ${ }^{[11]}$ We planned this study to investigate the characteristics of the newborns retrospectively in company with the literature, who were hospitalized in NICU, of the mothers diagnosed with maternal PE/E.

\section{Methods}

The discharge reports received from the hospital information management system (HIMS) for the newborns monitored, examined and treated in the NICU, whose mothers were followed up with the diagnosis of preeclampsia/eclampsia in a training and research hospital, received tertiary perinatology healthcare service and delivered in the same hospital between January 1 and December 31, 2018, were assessed retrospectively after obtaining the approvals of hospital management and ethics committee (Non-Invasive Ethics Committee of Scientific Researches, Faculty of Medicine, Sakarya University, File No: 02/10/2019-99). The study protocol was prepared in accordance with the 2008 Declaration of Helsinki. The data of the study were collected from HIMS on October 3-25, 2019 after obtaining necessary approvals.

The data of the women related with their pregnancies and deliveries (age, number of pregnancy, number of living children, number of miscarriage, conception method, delivery type, and the sex of newborn) and the data of the newborns hospitalized and followed up at the NICU (gestational age, birth weight, birth type, Apgar score, respiration support, time of switching to full enteral, number of hospitalization days, number of postnatal discharging days, weight at discharge, nutrition type and reasons for leaving the clinic) obtained from the discharge reports in patient files were analyzed.

The statistical analyses of the study were performed by using SPSS 21.0 (SPSS Inc., Chicago, IL, USA). Descriptive statistics were presented as mean and standard deviation for the continuous variables while percentage and frequency values were presented for the categorical variables.

\section{Results}

A total of 372 newborns were hospitalized in the NICU between January 1 and December 31, 2018, and 51 $(13.70 \%)$ of them were hospitalized due to the diagnosis 
of $\mathrm{PE} / \mathrm{E}$ in their mothers. The mean age of these mothers was $32.21 \pm 6.20$ (range: $18-44$ ) years, week of gestation (WG) that the newborns were born was $34.21 \pm 3.33$ (range: 26-40), and the mean birth weight (BW) was $2177 \pm 1007$ (range: 670-4730) g. It was found that almost all women (98\%) conceived spontaneously, 9.8\% $(n=5)$ of them were twin pregnancies, and $31.4 \%(n=16)$ of them had other diseases in addition to $\mathrm{PE} / \mathrm{E}$ (gestational diabetes, epilepsy, and hypothyroid). It was also found that $35.3 \%(n=18)$ of the women with $\mathrm{PE} / \mathrm{E}$ were experiencing their first pregnancy and it was their first delivery in $41.1 \%(n=21)$ of them while $41.2 \%(n=21)$ of them had at least one living child and $29.4 \% \quad(n=15)$ underwent miscarriage previously. According to the pregnancy history of the mothers, the numbers of conception were varying between 1 and 9 while the numbers of living children and undergoing miscarriage were varying between 1 and 4 . Of the deliveries, 96.1\% $(n=49)$ were carried out by cesarean section and $3.9 \%$ $(n=2)$ by normal vaginal method, and $49 \%(n=25)$ of the newborns were male and $51 \%(n=26)$ of them were female (Table 1).

It was found that $37.3 \%(\mathrm{n}=19)$ of the newborns were born at 26-32 weeks of gestation, $62.7 \%(n=32)$ of them born at 33-40 weeks of gestation while $66.7 \%(n=36)$ of them were born $670-2500 \mathrm{~g}$ and $33.3 \%(\mathrm{n}=15)$ of them were born 2501-4730 g. According to the antenatal (in obstetric ultrasound) and postnatal (at the end of labor) evaluations of the newborns, it was seen that $41.7 \%$ $(n=21)$ of them were diagnosed with IUGR, the mothers of 7 newborns were diabetic, 3 newborns had cardiac anomaly, the mothers of 2 newborns had oligohydramnios, the mother of 1 newborn had placenta previa, and the mother of 1 newborn had ablatio placentae. According to the Apgar scores, the scores of 56.9\% $(n=29)$ of them were 8 and above, and $43.1 \%(n=22)$ were 7 and below. When $31.4 \%$ of the newborns did not start to cry right after they were born, positive pressure ventilation (PPV) was performed as spontaneous respiration did not start. For the procedure of patient safety, all newborns were transferred to the NICU from the delivery room in a transport incubator accompanied by a pediatrician. During this transfer, $80.4 \%(n=41)$ of the newborns required respiration support. On the days that the newborns were hospitalized in the NICU, $58.8 \%$ of them received nasal continuous positive airway pressure (N-CPAP) support, $5.9 \%$ of them received mechanical ventilation (MV) support, and $51 \%$ of them received
Table 1. Pregnancy and delivery data of preeclamptic/eclamptic mothers.

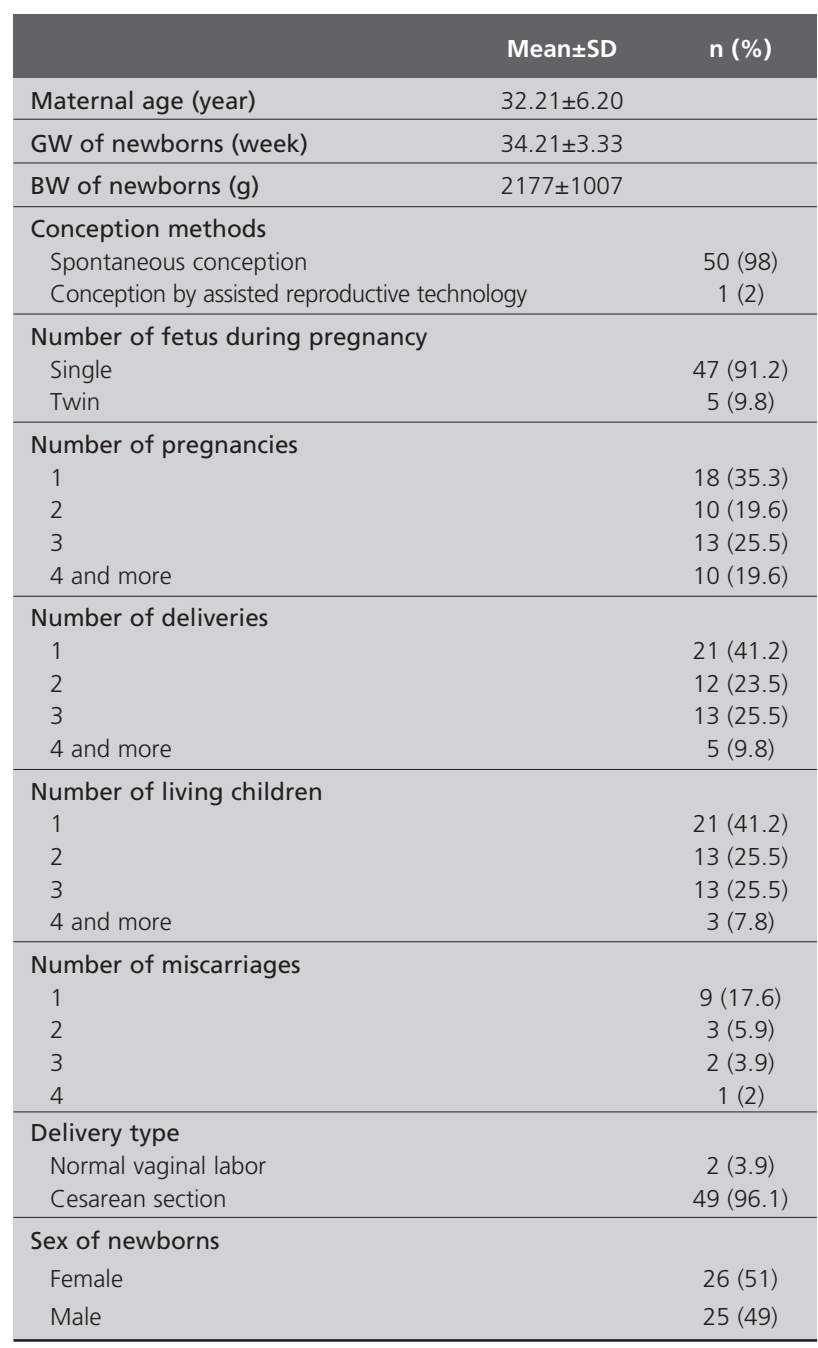

BW: birth weight; GW: week of gestation; Mean \pm SD: mean \pm standard deviation

intermittent phototherapy. On the first day of the hospitalization, the antibiotherapy was initiated for $76.5 \%$ of the newborns and the methylxanthine treatment was initiated for 2 newborns with apnea attack who were born at 35 weeks of gestation with a weight of $1565 \mathrm{~g}$ and born at 31 weeks of gestation with a weight of 1230 $\mathrm{g}$, respectively. The nourishment of the newborns at the intensive care unit were carried out mainly by breastfeed, and the mean day of switching to full enteral was 10.72 \pm 13.87 (range: $1-64$ ) days (Table 2).

Of the 51 newborns, 3 died on the 2nd, 12th and 23rd days of their hospitalization (the causes of their 
Table 2. Data of the newborns taken to the neonatal intensive care unit.

\begin{tabular}{|c|c|c|}
\hline & Mean \pm SD & n (\%) \\
\hline \multicolumn{3}{|l|}{ According to GW } \\
\hline $26-32$ & & $19(37.3)$ \\
\hline $33-40$ & & $32(62.7)$ \\
\hline \multicolumn{3}{|l|}{ According to BW } \\
\hline $670-2500 \mathrm{~g}$ & & $36(66.7)$ \\
\hline $2501-4730 \mathrm{~g}$ & & $15(33.3)$ \\
\hline \multicolumn{3}{|l|}{ Apgar score } \\
\hline 8 and above & & $29(56.9)$ \\
\hline 7 and below & & $22(43.1)$ \\
\hline \multicolumn{3}{|l|}{ Respiration support } \\
\hline N-CPAP & & $30(58.8)$ \\
\hline MV & & $3(5.9)$ \\
\hline Day of switching to full enteral & $10.72 \pm 13.87$ & \\
\hline
\end{tabular}

BW: birth weight; GW: week of gestation; Mean \pm SD: mean \pm standard deviation; MV: mechanical ventilation; N-CPAP: nasal continuous positive airway pressure; NICU: neonatal intensive care unit.

deaths were encephalocele, pulmonary hemorrhage, and cardiac anomaly, respectively), one newborn was dispatched to an external center (due to the unavailability of the unit), and 47 were discharged from the NICU with full recovery. The weeks of gestation and birth weights of the newborns which died were $31 \mathrm{WG}$ and $1450 \mathrm{~g}, 27 \mathrm{WG}$ and $740 \mathrm{~g}$, and $32 \mathrm{WG}$ and $1210 \mathrm{~g}$, respectively. Their mean day of hospitalization in the unit was $16.42 \pm 19.24$ (range: $1-91$ ) days, the day that they were discharged was $17.12 \pm 19.64$ (range: 9-91) days, and the mean weight at the discharge was $2464.85 \pm 740.75$ (range: $1600-4470$ ) g. Of the newborns, $90.2 \%$ were fed by only breastfeeding while $9.8 \%$ were fed by both breastfeeding and formula before they were discharged. It was found that the examination for

Table 3. The data of the neonatal intensive care unit newborns during discharge.

\begin{tabular}{lcc}
\hline Variables & Mean \pm SD & $\mathbf{n}(\%)$ \\
\hline Number of hospitalization days & $16.42 \pm 19.24$ & \\
\hline Number of postnatal discharge days & $17.12 \pm 19.64$ & \\
\hline Weight at discharge & $2464.85 \pm 740.75$ \\
\hline Nutrition at discharge & \\
Breastfeeding & $46(90.2)$ \\
Breastfeeding and formula together & $5(9.8)$ \\
\hline Reason for leaving the clinic & \\
Discharge with full recovery & $47(92.1)$ \\
Death & $3(5.9)$ \\
Dispatch & $1(2)$ \\
\hline
\end{tabular}

Mean \pm SD: mean \pm standard deviation. retinopathy of prematurity (ROP) of 9 newborns, who were prepared to be discharged and whose delivery week was between 27 and 32 and birth weight was between 670 and $1900 \mathrm{~g}$, were performed in the clinic (Table 3). The routines of the clinic, which were echo examination, full abdomen ultrasonography, Transfontanelle ultrasonography, hearing screening, national metabolic screening and vaccine schedule, were carried out before the newborns were discharged.

\section{Discussion}

Preeclampsia, which is very common today, has been one of the significant health issues as it causes serious complications both in the pregnant women and the newborns during their intrauterine period and preterm labors in particular. Fetal death, intrauterine growth retardation and premature labor are among the significant potential fetal and neonatal complications in the newborns of preeclamptic mothers. ${ }^{[12]}$ There may be different clinical features between the newborns of preeclamptic mothers and the newborns of healthy mothers. In their study, Acunaş et al ${ }^{[13]}$ compared the premature newborns of preeclamptic and normotensive mothers in terms of the prognosis and they did not find any statistically significant difference between two groups. The different results in these studies show that the impacts of preeclampsia on the newborns and their clinical outcomes vary although the problems encountered by the newborns of preeclamptic mothers after delivery are known. Hoffman et al. ${ }^{[14]}$ and Bahia et al. ${ }^{[15]}$ suggested that the cardiovascular system diseases such as preeclampsia increase with the pregnancies at advanced ages $(>35)$. Salem et al. ${ }^{[16]}$ showed a linear relationship between maternal age and perinatal complications in their study. In our study, mean age of the mothers was $32.21 \pm 6.20$ years. In the study of Çetin et al. ${ }^{[17]}$ retrospectively conducted on 16,294 patients, the authors found that the rates of preeclampsia and gestational hypertension were higher in nulliparous cases than the multiparous cases. We found in our study that $58.8 \%$ of our cases were multiparous although the preeclampsia is more common in primigravida cases.

Miyake et al. ${ }^{[18]}$ found in their retrospective study that the preeclampsia increased the rates of cesarean section, and the massive maternal hemorrhage increased. In our study, we found that $96.1 \%$ of the mothers delivered by 
the cesarean section. Of the newborns included in the study, $37.2 \%$ were between 26 and 32 weeks of gestation. Since the mothers of these newborns were significantly preeclampsia, the perinatology team performed preterm delivery for medical purpose. Today, prematurity and related early week of gestation and low birth weight are among the most important risk factors for the newborns of preeclamptic women. ${ }^{[19]}$ Çetinkaya et al. ${ }^{[20]}$ compared the newborns of preeclamptic mothers and normotensive in their study and they found that the birth weights of the newborns of preeclamptic mothers were lower than the control group. In our study, the mean birth weight of the newborns of preeclamptic mothers was $2177 \mathrm{~g}$.

There is no certain opinion on the RDS rates of the newborns of the preeclamptic mothers. Chang et al. ${ }^{[21]}$ found in their study where they investigated the RDS prevalence in the newborns of preeclamptic and nonpreeclamptic mothers that RDS rate was two times higher in the newborns of preeclamptic mothers whose gestational age was lower than 32 weeks and they did not find any difference between the groups for the newborns over 32 weeks in terms of RDS prevalence. Jelin et al. ${ }^{[22]}$ found in their retrospective study that RDS rates were increased in the newborns of the preeclamptic mothers, and they also found in their other study ${ }^{[23]}$ that RDS rates were higher in the newborns of preeclamptic mothers born at 32-37 weeks compared to the non-preeclamptic cases. In our study, we found that half (49\%) of the newborns were diagnosed with RDS. The differences in the definition of respiratory distress syndrome and carrying out studies retrospectively may be the reason for these differences.

We found that $58.8 \%$ of the newborns taken to the NICU received N-CPAP support and 5.9\% of them received MV support during their hospitalization at the NICU. Başkan et al. ${ }^{[24]}$ reported in their studies that $11.4 \%$ of the newborns of the preeclamptic mothers received MV support. Güran et al. ${ }^{[2]}$ evaluated the preeclamptic mothers' newborns with low birth weights and found that $51.9 \%$ of them needed MV. In the literature, RDS is the first reason for applying mechanical ventilation in the newborns with low birth weights. This increases the need for following up the newborns of preeclamptic mothers at a tertiary neonatal intensive care unit. We found that $90.2 \%$ of the newborns discharged from the NICU were fed by breastfeeding only.
This rate can be interpreted as a consistent result with the literature. ${ }^{[26]}$ Güran et al. ${ }^{[25]}$ reported in their study that $18.9 \%(n=10)$ of the newborns of 53 preeclamptic mothers had neonatal mortality. We found neonatal mortality only in $3(5.9 \%)$ cases in our study.

\section{Conclusion}

Preferring the delivery of pregnant women for the treatment of preeclampsia mostly as it decreases maternal and fetal mortality has made the iatrogenic prematurity one of the most common problems encountered by the newborns of the preeclamptic mothers. In the approach towards the newborns of preeclamptic women, we believe that perinatal mortality and morbidity associated with preeclampsia will be decreased by noticing all issues early that may develop, such as prematurity and the complications developing secondary to prematurity in particular, improving the conditions of the NICU, and establishing multidisciplinary teams

Conflicts of Interest: No conflicts declared.

\section{References}

1. Arıkan DC, Arikan T. Plasma selenium levels in pregnant women with preeclampsia. Perinatal Journal 2017;25:53-8.

2. Wagner LK. Diagnosis and management of preeclampsia. Am Fam Physician 2004;70:2317-24.

3. Durgun Ozan Y, Ertuğrul M, Okumuş H. Preeklampsi tanılama, değerlendirme ve hemşirelik yönetimi. Cumhuriyet Nursing Journal 2012;2:59-65.

4. Değirmenci H. Gebelerde hipertansiyona güncel yaklaşım. Erzincan Tip Dergisi 2018;1:20-7.

5. Chappell LC, Green M, Marlow N, Sandall J, Hunter R, Robson S, et al. Planned delivery or expectant management for late preterm preeclampsia: study protocol for a randomised controlled trial (PHOENIX trial). Trials 2019;20:85.

6. Raney JH, Morgan MC, Christmas A, Sterling M, Spindler H, Ghosh R, et al. Simulation-enhanced nurse mentoring to improve preeclampsia and eclampsia care: an education intervention study in Bihar, India. BMC Pregnancy Childbirth 2019;19:41.

7. Turgut A. HELLP sendromu ve ağır preeklampsi olgularında maternal ve fetal sonuçların karşılaştırılması. Uzmanlık tezi. T.C. Sağlık Bakanlığı Zeynep Kamil Kadın ve Çocuk Hastalıkları Eğitim ve Araştırma Hastanesi Kadın Hastalıkları ve Doğum Kliniği, İstanbul, 2008. p. 10-21.

8. Selçuk SN, Yurdakök M. Preeklamptik anne bebekleri. Çocuk Sağlığı ve Hastalıkları Dergisi 2015;58:110-22.

9. Karadeniz L, Çoban A, İnce Z, Türkoğlu Ü, Can G. Preeklamptik anne bebeklerinin kordon kanı kardiyak troponin 
T ve proteine bağlı olmayan demir düzeyleri. Çocuk Dergisi 2008;8:30-6.

10. Bursal Duramaz B, Bilgin L, Salihoğlu Ö, Ertaş K, Hatipoğlu $\mathrm{S}$. Neonatal outcomes of preterm infants born to preeclamptic mothers. Marmara Medical Journal 2017;30:8-13.

11. Başol G, Uzun ND, Uzun F, Kale A, Terzi H. Retrospective analysis of the preeclampsia cases delivered in our clinic between 2013 and 2017. Perinatal Journal 2018;26:135-40.

12. Akdağ AM. Preeklamptik anne bebekleri ile normal anne bebeklerinin demografik, laboratuar ve klinik özelliklerinin karşılaştırılması. Tıp Araştırmaları Dergisi 2014:12:125-30.

13. Acunaş B, Varol F, Vatansever Ü, Soyuçen E, Karasalihoğlu S. Neonatal outcome of premature infants of preeclamptic mothers. Gynecology Obstetrics \& Reproductive Medicine 2002;8: 14-6.

14. Hoffman MC, Jeffers S, Carter J, Duthely L, Cotter A, González-Quintero VH. Pregnancy at or beyond age 40 years is associated with an increased risk of fetal death and other adverse outcomes. Am J Obstet Gynecol 2007;196:e11-3.

15. Jahromi BN, Husseini Z. Pregnancy outcome at maternal age 40 and older. Taiwan J Obstet Gynecol 2008;47:318-21.

16. Salem Yaniv S, Levy A, Wiznitzer A, Holcberg G, Mazor M, Sheiner E. A significant linear association exists between advanced maternal age and adverse perinatal outcome. Arch Gynecol Obstet 2011;283:755-9.

17. Aslan Çetin B, Köroğlu N, Yalçın Bahat P, Akça A, Barut S. Effect of parity on obstetric outcomes in advanced maternal age pregnancies. [Article in Turkish] Okmeydanı Tip Dergisi $33: 130-3$.

18. Miyake H, Iwasaki N, Nakai A, Suzuki S, Takeshita T. The influence of assisted reproductive technology on women with pregnancy-induced hypertension: a retrospective study at a Japanese regional perinatal center. J Nippon Med Sch 2010; $77: 312-7$

19. Nomura Y, John RM, Janssen AB, Davey C, Finik J, Buthmann J, et al. Neurodevelopmental consequences in offspring of mothers with preeclampsia during pregnancy: underlying biological mechanism via imprinting genes. Arch Gyn Obstet 2017;295:1319-29.

20. Cetinkaya M, Ozkan H, Köksal N, Karali Z, Ozgür T. Neonatal outcomes of premature infants born to preeclamptic mothers. J Matern Fetal Neonatal Med 2010;23:425-30.

21. Chang EY, Menard MK, Vermillion ST, Hulsey T, Ebeling $M$. The association between hyaline membrane disease and preeclampsia. Am J Obstet Gynecol 2004;191:1414-7.

22. Jelin AC, Cheng YW, Shaffer BL, Kaimal AJ, Little SE, Caughey AB. Early-onset preeclampsia and neonatal outcomes. J Matern Fetal Neonatal Med 2010;23:389-92.

23. Jelin AC, Kaimal AJ, Kuzniewicz M, Little SE, Cheng YW, Caughey AB. Preterm preeclampsia: 32 to 37 weeks gestation. J Matern Fetal Neonatal Med 2012;25:2198-201.

24. Başkan AK, Salihoğlu Ö, Tan İ, Akyol B, Hatipoğlu S. Mortality and morbidity analysis in neonates supported by invasive mechanical ventilation. Journal of Clinical and Experimental Investigations 2012;3:483-92.

25. Güran Ö, Uslu S, Bülbül A, Çelik M, Baş EK, Arslan S, et al. Early neonatal outcomes of very low birth weight infants of preeclamptic mothers. [Article in Turkish] Journal of Academic Research in Medicine 2012;2:64-7.

26. Türkiye Nüfus ve Sağlık Araştırması (TNSA) 2013. Ankara: Hacettepe Üniversitesi Türkiye Nüfus Etütleri Enstitüsü; 2013.

Bu makalenin kullanım izni Creative Commons Attribution-NoCommercial-NoDerivs 3.0 Unported (CC BY-NC-ND3.0) lisans1 aracılı̆̆ılya bedelsiz sunulmaktadır. / This work is licensed under the Creative Commons Attribution-NonCommercial-NoDerivs 3.0 Unported (CC BY-NC-ND3.0) License. To view a copy of this license, visit http://creativecommons.org/licenses/by-nc-nd/3.0/ or send a letter to Creative Commons, PO Box 1866 , Mountain View, CA 94042, USA. 